\title{
MACK HENDRICKS SINGLETON
}

$(1908-1980)$

Professor Mack Singleton, a native Kentuckian but transplanted to Oklahoma in his boyhood, died at age 72 in Madison on August 10 after a lengthy illness. He had been devoting his time since retirement to the completion of a book on Cervantes and to extensive notes to the Libro de buen amor, both of which projects were left uncompleted. Except for the years 1939 to 1947, when he was at Queens College (New York) and in army intelligence in Europe, his entire teaching career was connected with the University of Wisconsin where there long were two Celestina scholars: Dean J. H. Herriott and Mack Singleton.. Both gave frequent seminars in the Celestina and produced a series of scholars who continue to devote themselves to this masterpiece.

Professor Singleton was extraordinarily sensitive to the qualities of the English language, and nowhere did he bring this gift to bear better than on his transiation of the Celestina. This English version, published by the University of Wisconsin Press, has had very wide circulation. The play in his translation was presented twice on the Wisconsin campus, once as a feature of the Modern Language Association program when they met one summer in Madison. The role of Pleberio was on one occasion very effectively presented by the translator.

It is noteworthy that Professor Singleton devoted his scholarship to the greatest works and authors of earlier Spanish literature: the Poema de Mio Cid, Juan Ruiz, the Celestina, Cervantes, and Góngora. His wide acquaintance with classical and medieval literatures provided a formidable background for his inspiring and challenging teaching. In the course of his many years at Wisconsin he guided hundreds of students to a better understanding of these literary monuments and of themselves.

LLOYD KASTEN

University of Wisconsin-Madison

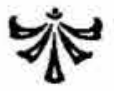


A play in twenty-one acts

attributed to

Fernando de Rojas

(i)

(2).

sitis

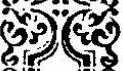

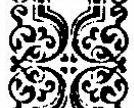

कुज (c)

Sig

Celestina

Translated from the Spanish by

MACK HENDRICKS SINGLETON

and publisbed by

The University of Wisconsin Press

Madison, 1958

Title page of M. H. Singleton's English translation of Rojas's Tragicomedia. 